\title{
Polymorphism and Association of 5'UTR CAPN1 Gene with Growth Traits in Bali Cattle by PCR-RFLP
}

\author{
D. E. W. T. Sihite ${ }^{\mathrm{a}, \mathrm{b}}$, R. Priyanto ${ }^{\mathrm{b}}$, \& Jakaria ${ }^{\mathrm{b}, *}$ \\ ${ }^{a}$ Magister Program in Animal Science, Faculty of Animal Science, IPB University (Bogor Agricultural University) \\ bDepartment of Animal Production and Technology, Faculty of Animal Science, \\ IPB University (Bogor Agricultural University) \\ Jalan Agatis, Kampus IPB Darmaga Bogor 16680, Indonesia \\ ${ }^{*}$ Corresponding author: jakaria_karman@yahoo.co.id \\ (Received 06-02-2019; Revised 22-05-2019; Accepted 27-05-2019)
}

\begin{abstract}
The aim of this study was to identify the variation of 5'UTR CAPN1 gene and its association to growth traits in Bali cattle. DNA samples were obtained from 80 heads of Bali cattle originated from BPTU-HPT Denpasar. The average of Bali cattle age was 784 days (631 days-1098 days). Bali cattle were divided into 3 age groups namely, the first group (1.5 years to 2 years), the second group ( 2 years to 2.5 years), and the third group (2.5 years to 3 years). The observed growth traits were birth weight $(\mathrm{kg})$, live weights $(\mathrm{kg})$, average daily gain $(\mathrm{kg})$, body length $(\mathrm{cm})$, chest depth $(\mathrm{cm})$, withers height $(\mathrm{cm})$, hip height $(\mathrm{cm})$, and heart girth $(\mathrm{cm})$. Polymorphism identification of 5’UTR CAPN1 gene was conducted by Polymerase Chain Reaction-Restriction Fragment Length Polymorphism (PCR-RFLP) with BglII as the restriction enzyme. Growth traits data association were analyzed using the General Linear Model (GLM) analysis. The 5'UTR CAPN1 genelBglII was polymorphic in Bali cattle (GG, GT, and TT). Genotype frequencies for Bali cattle were 0.30 (GG), 0.66 (GT), and 0.04 (TT). The allele frequencies of $G$ and $T$ allele were 0.63 and 0.37 , respectively. The $G$ allele was the most frequent allele and GT genotype was the most frequent genotype among the cattle. The CAPN1।BglII had a significant effect $(p<0.05)$ on growth traits in Bali cattle. Animal carrier of GG genotype had higher live weight and average daily gain than those with GT genotype, while the lowest values were associated with TT genotype.
\end{abstract}

Keywords: 5'UTR; Bali cattle; CAPN1 gene; PCR RFLP

\section{INTRODUCTION}

Selection for growth traits in Bali cattle is mostly conducted by traditional phenotypical selection methods. Today, molecular-based selection in cattle has been widely performed in other countries, including Indonesia. One of the genes that affect meat quality and growth traits is Calpain (CAPN1). Calpain is a group of neutral cysteine proteinase affected by calcium. Calpain 1 (CAPN1) is located on chromosome 29 (Pinto et al., 2010) consisting of 21 exons and 20 introns (Dear et al., 2000). In the distal region of bovine chromosome 29 that spans CAPN1, there is a substantial overlap of QTLs (http://www.animalgenome.org). Apart from beef tenderness, these QTLs also regulate growth (weaning weight, carcass weight) and feed efficiency. CAPN1 is considered to be the best candidate for tenderness QTL, however, there is little information about the genes underlying the other QTLs in the region (Pintos \& Corva, 2011). CAPN1 gene has been reported to be associated with average daily gain, live weights, carcass weight, backfat thickness, m. longissimus thoracis et lumbo- rum, $\mathrm{pH}$, final weight, increased body weights in cattle (Ardicli, 2017; Miquel et al., 2009; Tait et al., 2014).

CAPN1 gene has a 5' untranslated region (UTR) which has been recognized for controlling translationinitiation process (Gunawan et al., 2017), post-translation process, and the regulation of gene expression. Mignone et al. (2002) state that 5'UTR is one of mRNA elements contributing significantly to the translation efficiency of an mRNA. Certain features can suggest translational control of the messenger when a 5'UTR sequence is analyzed.

Numerous studies on 5'UTR fragment have also been reported in chicken (Bhattacharya et al., 2011; Korwin-Kossakowska et al., 2009), sheep (Sjakste et al., 2011; McKenzie et al., 2012; Sahu et al., 2016), pig (Shen et al., 2011; Brenig et al., 2015; Fang et al., 2011), and cattle (Öner et al. 2017; Manzoor et al., 2013; Sugimoto et al., 2012). There were 43 SNPs and three indels were found in the 5' UTR region in HSP70.1 gene in Turkish cattle breeds (Yerli Kara (YK), Boz irk (BI), Yerli Güney Sarısı (YGS), Güney Doğu Anadolu Kırmızısı (GAK), Doğu Anadolu Kırmızısı (DAK)), and Holstein Friesian 
(Siyah Alaca (SA). HSP70.1 is a member of the heat stress protein family, which is essential for life, production, and reproduction in cattle. The 5' UTR region of HSP70.1 gene was more variable in the Turkish native breeds than in the Holstein Friesian (Öner et al. 2017). Another study also stated that there was a significant finding of the incidence of the $\mathrm{C} \rightarrow \mathrm{T}$ polymorphism in 5'UTR CYP11B1 gene in Pakistan Sahiwal cattle breed (Manzoor et al., 2013). Khasanah et al. (2016) stated that myostatin (MSTN) promoter gene was polymorphic in Bali cattle and associated with intramuscular fat percentage. From the studies above, no study was conducted in Bali cattle. The results of the previous studies suggested that 5'UTR CAPN1 might also have a marked influenced on Bali cattle genetic performance. The aims of this study were to identify variation in 5'UTR CAPN1 gene and its association with growth traits in Bali cattle.

\section{MATERIALS AND METHODS}

\section{Samples}

This research was conducted in the laboratory of animal molecular genetics, Faculty of Animal Science, IPB University (Bogor Agricultural University). Blood samples were obtained from 80 heads of Bali cattle in BPTU-HPT Denpasar. The average of Bali cattle age was 784 days (631 days-1098 days). Bali cattle were divided into 3 age groups namely, the first group (1.5 years to 2 years), the second group (2 years to 2.5 years), and the third group (2.5 years to 3 years). The observed growth traits were birth weight $(\mathrm{kg})$, live weights $(\mathrm{kg})$, average daily gain $(\mathrm{kg})$, body length $(\mathrm{cm})$, chest depth $(\mathrm{cm})$, withers height $(\mathrm{cm})$, hip height $(\mathrm{cm})$, and heart girth (cm).

\section{DNA Isolation and PCR Amplification}

Blood samples were collected from the jugular vein of the Bali cattle and kept in a vacutainer tube containing ethanol absolute as an anticoagulant. Extraction of DNA was carried out by a modified DNA Geneaid Kit. The primer was designed using data sequences from the National Center for Biotechnology Information (NCBI) with access number AH009246.3. Primer selection was performed by using Primer 3, Multiple Primary Analyzer, and Primary Stat. Forward primer was 5-CCC TTC CCA CCC AGA TAG G-`3 and reverse forward was 5’-CCT GGA GAC CGT GAG GAA C-‘3. The primer was designed to amplify 5'UTR region of CAPN1 gene. For the PCR, $25 \mu \mathrm{L}$ of PCR amplification mix contained $1 \mu \mathrm{L}$ of DNA template contained $50 \mathrm{ng}$ of DNA template, $12.5 \mu \mathrm{L}$ of PROMEGA green master mix, $10.9 \mu \mathrm{L}$ of nuclease-free water, $0.3 \mu \mathrm{L}$ contained 5 pmol forward primer, and $0.3 \mu \mathrm{L}$ contained 5 pmol reverse primer. The DNA amplification was conducted in predenaturation condition at $95^{\circ} \mathrm{C}$ for 5 minutes, annealing at $55^{\circ} \mathrm{C}$ for 20 seconds, extension at $72^{\circ} \mathrm{C}$ for 30 seconds, and a final extension at $72^{\circ} \mathrm{C}$ for $5 \mathrm{~min}$. The amplification process was carried out for 35 cycles. The expected amplified fragment size for CAPN1 gene was $478 \mathrm{bp}$.

\section{Genotyping}

Restriction enzyme was designed by NEBCutter v2.0 program. BglII was found as restriction enzyme with the site cut (AIGATCT). Polymorphism of 5'UTR CAPN1 was examined by PCR-RFLP method. A mixture containing $5 \mu \mathrm{L}$ of PCR product, $0.9 \mu \mathrm{L}$ of nuclease-free water, $0.7 \mu \mathrm{L}$ of BglII enzyme buffer, and $0.4 \mu \mathrm{L}$ contained $4 \mathrm{U} / \mu \mathrm{L}$ of BglII enzyme was incubated at $65^{\circ} \mathrm{C}$ for 4 hours. The products were then electrophoresed in $2 \%$ agarose gel for 35 minutes and photographed with a gel imaging system (UV Transilluminator). GG genotype had 478 bp fragment, TT genotype had 354 bp and 124 bp fragments, and GT genotype had 478 bp, 354 bp, and 124 bp fragments.

\section{Data Analysis}

Genotype and allele frequency. The genotype and allele frequency were calculated using Popgene32 according to Nei \& Kumar (2000) with the formula as follows: $\chi_{\mathrm{ii}}=\left(\mathrm{n}_{\mathrm{ii}} / \mathrm{N}\right)$ for genotype frequency and $\chi_{\mathrm{i}}=\left(2 \mathrm{n}_{\mathrm{ii}}+\Sigma \mathrm{n}_{\mathrm{ij}}\right) /(2 \mathrm{~N})$ for allele frequency, where: $\chi_{\mathrm{ii}}$ is frequency of ii genotype; $\chi_{i}$ is frequency of $i$ allele; $n_{i i}$ is number of individuals with ii genotype; $n_{i j}$ is number of individuals with ij genotype; and $\mathrm{N}$ is number of samples.

Hardy-Weinberg equilibrium (HWE). Hardy-Weinberg equilibrium was determined using Popgene32 program, the Chi-Square equation (Hartl \& Clark, 1997) as follows:

$\left.\chi^{2}=\sum\left\{(\mathrm{O}-\mathrm{E})^{2}\right) / \mathrm{E}\right\}$

where: $\chi^{2}$ is HWE test; $\mathrm{O}$ is the observed number of genotypes; $\mathrm{E}$ is the expected number of genotypes. $\mathrm{df}=$ number of genotype probabilities - number of alleles.

CAPN1 gene association with growth traits. Growth traits data of Bali cattle were analyzed using General Linear Model (GLM) by SAS software. Further tests were carried out by Least Square Means. A mathematical model was formulated as follows:

$\mathrm{Y}_{\mathrm{ij}}=\mu+\alpha_{\mathrm{i}}+\beta_{\mathrm{j}}+\gamma_{\mathrm{k}}+\mathrm{E}_{\mathrm{ijkl}}$

where: $\mu$ is overall mean for each trait; $\alpha_{i}$ is the effect of $\mathrm{i}^{\text {th }}$ genotype, $\mathrm{i}$ is $1,2,3 ; \beta_{\mathrm{j}}$ is the effect of $\mathrm{j}^{\text {th }}$ sex, $\mathrm{j}$ is 1,$2 ; \gamma_{\mathrm{k}}$ is the effect of $\mathrm{k}^{\text {th }}$ age group, and $\mathrm{k}$ is $1,2,3$; $\mathrm{e}_{\mathrm{ijkl}}$ is random error.

\section{RESULTS}

\section{Polymorphism of 5'UTR of CAPN1 Gene}

The 5'UTR of CAPN1 gene of Bali cattle was successfully amplified using a pair of primer at an annealing temperature of $55^{\circ} \mathrm{C}$ for $20 \mathrm{~s}$ (Figure 1). The length of PCR product was $478 \mathrm{bp}$. Genotyping using BglII as the restriction enzyme resulted in three genotypes: GG (478 bp), TT (354 and 124 bp), and GT (478, 354, and 124 bp).

The 5'UTR CAPN1 gene was polymorphic in Bali cattle. The polymorphism of 5'UTR gene in Bali cattle 
are presented in Figure 2. The genotype frequencies were 0.30 (GG), 0.66 (GT), and 0.04 (TT). The allele frequencies of $\mathrm{G}$ and $\mathrm{T}$ were 0.63 and 0.37 respectively. The $\mathrm{G}$ allele was the most frequent allele and GT genotype was the most frequent genotype among the cattle.

\section{Association of CAPN1 Gene on Growth Traits}

Association analysis showed that the 5'UTR CAPN1 IBglII was significantly affected live weight and average daily gain in Bali cattle $(\mathrm{p}<0.05)$. Individuals with the GG genotypes had higher live weight and average daily gain than GT and TT genotypes $(p<0.05)$. The association result is presented in Table 1.

\section{DISCUSSION}

Calpain (CAPN1) is a group of neutral cysteine proteinase affected by calcium. Calpain substrates consist of a variety of enzymes such as cytoskeletal proteins (Fedota et al., 2016) and epidermal growth factor receptors (Glading et al., 2000). The CAPN gene was investigated as a potential candidate gene for growth trait as reported in earlier studies of Mahrous et al., 2016; Hou et al., 2011; and Bosques et al., 2015.

Amplification of CAPN1 gene in 5'UTR fragment was successfully conducted using PCR for all samples.
According to PCR-RFLP on 5'UTR CAPN1 gene using $\mathrm{Bg} I I I$ as restriction enzyme, the region was polymorphic in Bali cattle. It is because the allele frequency obtained is more than 0.01 (Nei \& Kumar, 2000). There were three genotypes (GG, GT, and TT) found in Bali cattle. The genotype frequencies were 0.30 (GG), $0.66(\mathrm{GT})$, and 0.04 (TT). The allele frequencies of $G$ and $T$ were 0.63 and 0.37 respectively. The variation in 5'UTR CAPN1 gene in Bali cattle in BPTU-HPT Denpasar were not in HardyWeinberg equilibrium, $\chi^{2}$ value was $13.92(\mathrm{p}<0.05)$. Gunawan et al. (2017) stated that a population was in Hardy-Weinberg equilibrium if the genotype frequencies of the dominant and recessive alleles were constant from generation to generation; there was no selection, mutation, migration, and genetic drift. Genotypefrequency imbalances of CAPN1 genelBglII suggested that the population of Bali cattle in BPTU-HPT Denpasar had undergone selection.

The result of growth traits association with 5'UTR CAPN1 IBglII showed that variations in 5'UTR CAPN1 gene significantly affected live weight and average daily gain in Bali cattle $(p<0.05)$ (Table 1$)$. Birth weight, body length, chest depth, withers height, hip height, and heart girth of Bali cattle with genotypes GG, GT, and TT had no significant difference based on Table 1 . The average birth weight of Bali bulls was $18.9 \pm 1.4 \mathrm{~kg}$ (Prasojo et al., 2010) and $17.73 \pm 1.72 \mathrm{~kg}$ (Gunawan \& Jakaria, 2011).

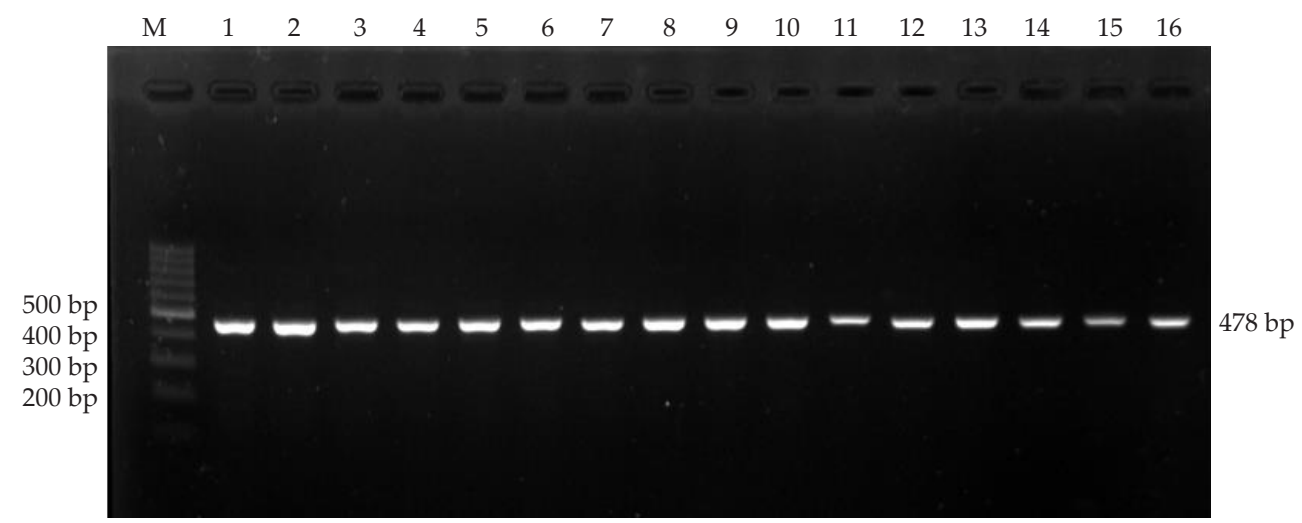

Figure 1. Amplification product of 5'UTR CAPN1 gene in Bali cattle in 1.5\% agarose gel (w/v). Lane M= marker with 100 bp DNA.

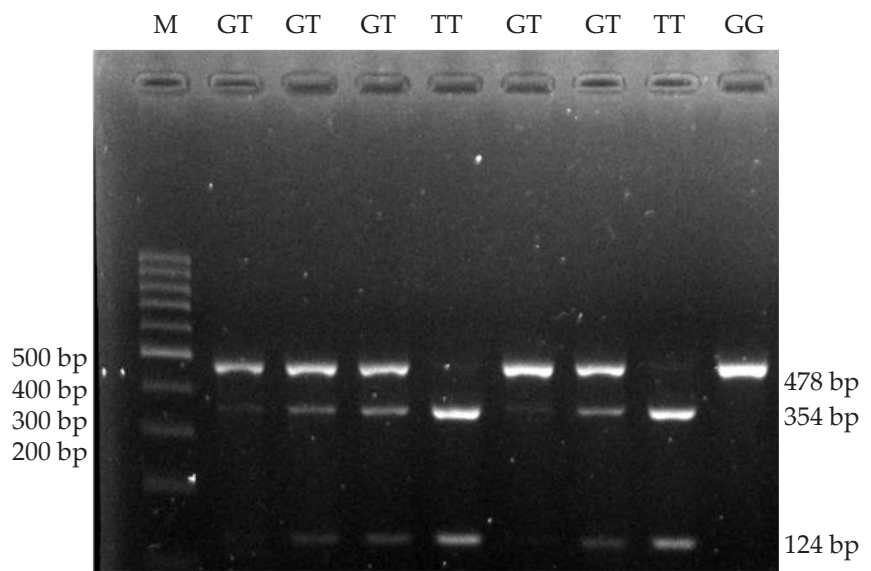

Figure 2. Amplification product of 5'UTR CAPN1 gene in Bali cattle in $2 \%$ agarose gel $(\mathrm{w} / \mathrm{v})$. Lane $\mathrm{M}=$ marker with 100 bp DNA.
Table 1. CAPN1 gene association with growth traits

\begin{tabular}{lccc}
\hline \multirow{2}{*}{ Traits } & \multicolumn{3}{c}{ Genotype } \\
\cline { 2 - 4 } & GG $(\mathrm{n}=24)$ & GT $(\mathrm{n}=53)$ & TT $(\mathrm{n}=3)$ \\
\hline Birth weight $(\mathrm{kg})$ & $17.9 \pm 0.5$ & $18.1 \pm 0.4$ & $19.3 \pm 1.2$ \\
Live weight $(\mathrm{kg})$ & $211.4 \pm 7.1^{\mathrm{a}}$ & $196.7 \pm 5.0^{\mathrm{b}}$ & $160.0 \pm 17.3^{\mathrm{c}}$ \\
Average daily & $0.248 \pm 0.010^{\mathrm{a}}$ & $0.225 \pm 0.007^{\mathrm{b}}$ & $0.177 \pm 0.024^{\mathrm{c}}$ \\
gain $(\mathrm{kg})$ & & & \\
Body length $(\mathrm{cm})$ & $106.4 \pm 1.8$ & $106.6 \pm 1.3$ & $102.5 \pm 4.5$ \\
Chest depth $(\mathrm{cm})$ & $57.0 \pm 0.9$ & $55.5 \pm 0.6$ & $56.1 \pm 2.2$ \\
Withers height & $110.7 \pm 1.1$ & $111.9 \pm 0.8$ & $108.9 \pm 2.7$ \\
(cm) & & & \\
Hip height $(\mathrm{cm})$ & $110.9 \pm 1.1$ & $119.5 \pm 0.8$ & $110.7 \pm 2.8$ \\
Heart girth $(\mathrm{cm})$ & $148.5 \pm 1.8$ & $144.7 \pm 1.3$ & $142.4 \pm 4.6$ \\
\hline
\end{tabular}

Note: means in the same row with different superscripts differ significantly $(\mathrm{p}<0.05)$. 
The average birth weights of Bali cows were 18.9 \pm 1.4 $\mathrm{kg}$ (Prasojo et al., 2010) and 17.55 $\pm 1.70 \mathrm{~kg}$ (Gunawan \& Jakaria, 2011).

Genotype GG was significant $(p<0.05)$ for the highest live weight and average daily gain in Bali cattle. This shows that 5'UTR CAPN1 I BglII can be used to select for live weight and average daily gain traits in Bali cattle. Miquel et al. (2009) found a significant association between CAPN1-316 marker with shear force, final weight, and average daily gain in Brangus and Angus steers. Pintos \& Corva (2011) also reported a significant association between CAPN1-316 marker with birth weight, calving weight, and 18 months weight. They stated that to get high tenderness in meat, the cattle can be selected for low average daily gain and low final weight.

\section{CONCLUSION}

The 5'UTR CAPN1 IBglII was polymorphic in Bali cattle and was not in Hardy-Weinberg equilibrium. Genotype GG was significant for the highest live weight and average daily gain in Bali cattle. Therefore, selection can be done by using 5'UTR CAPN1 IBglII in Bali cattle for live weight and average daily gain traits.

\section{CONFLICT OF INTEREST}

We certify that there is no conflict of interest with any financial, personal, or other relationships with other people or organization related to the material discussed in the manuscript.

\section{ACKNOWLEDGEMENT}

This research was financially supported by Penelitian Dasar Unggulan Perguruan Tinggi (PDUPT) program (1757/IT3.11/PN/2018). The authors would also like to give thank you to Balai Pembibitan Ternak Unggul dan Hijauan Pakan Ternak Bali (BPTU-HPT Bali) for providing blood sample of Bali cattle and growth trait data that were used in this study.

\section{REFERENCES}

Araujo, P. R., Y. Kihoon, K. Daijin, D. S. Andrew, M. Qiao, U. Suresh, C. B., Suzanne, \& O.F.P. Luiz. 2012. Before it gets started : regulating translation at 5'UTR [review]. Comp. Funct. Genom. 2012:1-8. https://doi. org/10.1155/2012/475731

Ardicli, S., H. Samli, D. Dincel, B. Soyudal, \& F. Balci. 2017. Individual and combined effects of CAPN1, CAST, LEP and GHR gene polymorphisms on carcass characteristics and meat quality in Holstein bulls. Arch. Anim. Breed. 60:303-313. https://doi.org/10.5194/aab-60-303-2017

Bhattacharya, T. K., R. N. Chatterjee, R. P. Sharma, M. Niranjan, \& U. Rajkumar. 2011. Associations between novel polymorphisms at the 5-UTR region of the prolactin gene and egg production and quality in chickens. Theriogenology. 75:655-661. https://doi.org/10.1016/j. theriogenology.2010.10.005

Bosques, J., M. Pagán-Morales, A. Casas, A. Rivera, \& , D. Cianzio. 2015. Effect of polymorphisms in the $\mu$-calpain and calpastatin genes on economically important traitsof beef cattle in Puerto Rico. The Journal of Agriculture of the
University of Puerto Rico. 99: 87-104.

Brenig, B., Y. Duan, Y. Xing, N. Ding, L. Huang, \& E. Schütz. 2015. Porcine SOX9 gene expression is influenced by an $18 \mathrm{bp}$ indel in the $5^{\prime}$-untranslated region. PLOS ONE. 10: 1-17. https://doi.org/10.1371/journal.pone.0139583

Dear, T. N., N. T. Meier, M. Hunn, \& T. Boehm. 2000. Gene structure, chromosomal localization, and expression pattern of CAPN12, a new member of the Calpain large subunit gene family. Genomics. 68:152-160. https://doi. org/10.1006/geno.2000.6289

Fang, M., H. Du, Y. Hu, X. Zhou, H. Ouyang, W. Zhang, X. Jia, J. Li, Y. Wang, Q. Nie, \& X. Zhang. 2011. Identification and characterization of the pig abin-1gene and investigation of its association with reproduction traits. J. Genet. 90: e10e20. https://doi.org/10.1007/s12041-011-0025-6

Fedota, O. M., S. Y. Ruban, N. G. Lysenko, A. I. Kolisnyk, \& I. V. Goraichuk. 2016. SNPS of Calpain/Calpastatin system genes in commercial population of Aberdeen Angus in Kharkiv region, eastern Ukraine. Journal for Veterinary Medicine, Biotechnology and Biosafety. 2:20-28.

Glading, A., P. Chang, D. A. Lauffenburger, \& A. Wells. 2000. Epidermal growth factor receptor activation of calpain is required for fibroblast motility and occurs via an ERK/ MAP kinase signaling pathway. J. Biol. Chem. 275: 23902398. https://doi.org/10.1074/jbc.275.4.2390

Gunawan, A. \& Jakaria. 2011. Genetic and non-genetics effect on birth, weaning, and yearling weight of Bali cattle. Med Pet. 34: 93-98. https://doi.org/10.5398/medpet.2011.34.2.93

Gunawan, A., C. Sumantri, \& R. Juniarti. 2017. Gen dan Keragaman Genetik Ternak. IPB Press, Indonesia.

Hartl, D. L. \& A. G. Clark. 1997. Principle of Population Genetic. Sinauer Associates, MA, United Kingdom.

Hou, G., H. Meng, G. Xue, L. Junya, G. Huijiang, R. Hongyan, \& X. Shangzhong. 2011. Association of Calpain 1 (CAPN1) and HRSP12 allelic variants in beef cattle with carcass traits. Afr. J. Biotechnol. 10: 13714-13718. https://doi. org/10.5897/AJB11.338

Khasanah, H., A. Gunawan, R. Priyanto, M. F. Ulum, \& Jakaria. 2016. Polymorphism of myostatin (MSTN) promoter gene and its association with growth and muscling traits in Bali cattle. Med Pet. 39: 95-103. https://doi.org/10.5398/ medpet.2016.39.2.95

Korwin-Kossakowska, A., J. Wyszynska-Koko, G. Sender, A. Gajewska, M. Pierzchala, M. Kamyczek, \& K. Kochman. 2009. Effect of the polymorphism in 5-UTR region of pig prolactin gene on prolactin gene expression and reproduction performance in the female pig. Neuro Endocrinol Lett. 30:221-226.

Mahrous, K. F., M. S. Hassanane, H. I. Shafey, M. A. Mordy, \& H. E. Rushdi. 2016. Association between single nucleotide polymorphism in ovine Calpain gene and growth performance in three Egyptian sheep breeds. J. Genet. Eng. Biotechnol. 14:233-240. https://doi.org/10.1016/j. jgeb.2016.09.003

Manzoor, S., A. Nadeem, M. Javed, \& M. E. Babar. 2013 Identification of single nucleotide polymorphism in 5'-UTR of CYP11B1 gene in Pakistani Sahiwal cattle. International Journal of Biotechnology and Bioengineering 7: 995-997.

McKenzy, G. W., R. Arora \& J. G. Hickford. 2012. Genetic variation in the 5'UTR of the KRT2.13 gene of sheep. Anim. Sci. J. 83:194-198.https://doi.org/10.1111/j.1740-0929.2011.00933.x

Mignone, F., C. Gissi, S. Liuni, \& G. Pasole. 2002. Untranslated regions of mRNAs. Rev. Genom. Biol. 3:0004.1-0.004.10. https://doi.org/10.1186/gb-2002-3-3-reviews0004

Miquel, M.C., E. Villarreal, C. Mezzadra, L. Melucci, L. Soria, P. Corva, \& A. Schor. 2009. The association of CAPN1 316 marker genotypes with growth and meat quality traits of steers finished on pasture. Genet. Mol. Biol. 32:491-496. https://doi.org/10.1590/S1415-47572009000300011 
Nei, M. \& S. Kumar. 2000. Molecular Evolution and Phylogenetics. Oxford Univ Press, United States of America.

Öner, Y., A. Keskin, H. Üstüner, D. Soysal, \& V. Karakaş. 2017. Genetic diversity of the $3^{\prime}$ and $5^{\prime}$ untranslated regions of the HSP70.1 gene between native Turkish and Holstein Friesian cattle breeds. South Afric.Anim Sci. 47: 424-439. https://doi.org/10.4314/sajas.v47i4.2

Pinto, L. F. B., J. B. S. Ferraz, F. V.Meirelles, J. P. Eler, F. M. Rezende, M. E. Carvalho, H. B.Almeida, \& R. C. G. Silva. 2010. Association of SNPs on CAPN1 and CAST genes with tenderness in Nellore cattle. Genet. Mol. Res. 9: 14311442. https://doi.org/10.4238/vol9-3gmr881

Pintos, D. \& P. M. Corva. 2010. Association between molecular markers for beef tenderness and growth traits in Argentinian Angus cattle. Anim. Genet. 42:329-332. https:// doi.org/10.1111/j.1365-2052.2010.02160.x

Prasojo, G., I. Arifiantini, \& K. Mohamad. 2010. Korelasi antara lama kebuntingan, bobot lahir dan jenis kelamin pedet hasil inseminasi buatan pada sapi bali. J. Vet. 11: 41-45.

Sahu, A.R., V. Jeichitra, R. Rajendran, \& A. Raja. 2016. Genetic polymorphism in 5'UTR of myostatin (MSTN) gene in Nilagiri sheep. Journal of Livestock Biodiversity 6:7-10. https://doi.org/10.5958/2277-940X.2016.00013.9
Shen, H., S. H.Zhao, J. H.Cao, X. Y. Li, \& B. Fan. 2011. Porcine MuRF2 and MuRF 3: molecular cloning, expression and association analysis with muscle production traits. Mol. Biol. Rep. 38:5115-5123. https://doi.org/10.1007/ s11033-010-0659-0

Sjakste, T., N. Paramonova, Z. Grislis, I. Trapina, \& D. Kairisa. 2011. Analysis of the single-nucleotide polymorphism in the 5'UTR and part of intron I of the sheep mstn gene. DNA Cell Biol. 30: 433-444. https://doi.org/10.1089/ dna.2010.1153

Sugimoto, M., T. Watanabe, \& Y. Sugimoto. 2012. The molecular effects of a polymorphism in the 5'UTR of solute carrier family 44, member 5 that is associated with birth weight in Holsteins. PloS ONE. 7: 1-10. https://doi.org/10.1371/journal.pone.0041267

Tait, R. G., S. D. Shackelford, T. L. Wheeler, D. A. King, E. Casas, R. M. Thallman, T. P. L. Smith, \& G. L. Bennett. 2014. $\mu$-calpain, calpastatin, and growth hormone receptor genetic effects on preweaning performance, carcass quality traits, and residual variance of tenderness in Angus cattle selected to increase minor haplotype and allele frequencies. J. Anim. Sci. 92:456-466. https://doi.org/10.2527/ jas.2013-7075 